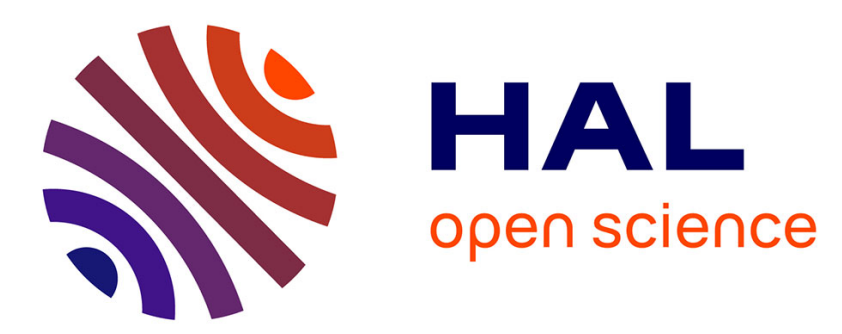

\title{
Short-term effects of two fungicides on enchytraeid and earthworm communities under field conditions
}

\author{
Joël Amossé, Sylvain Bart, Alexandre R.R. Pery, Céline Pelosi
}

\section{To cite this version:}

Joël Amossé, Sylvain Bart, Alexandre R.R. Pery, Céline Pelosi. Short-term effects of two fungicides on enchytraeid and earthworm communities under field conditions. Ecotoxicology, 2018, 27 (3), pp.300312. 10.1007/s10646-018-1895-7 . hal-01706193

\section{HAL Id: hal-01706193 \\ https://hal.science/hal-01706193}

Submitted on 29 Feb 2020

HAL is a multi-disciplinary open access archive for the deposit and dissemination of scientific research documents, whether they are published or not. The documents may come from teaching and research institutions in France or abroad, or from public or private research centers.
L'archive ouverte pluridisciplinaire HAL, est destinée au dépôt et à la diffusion de documents scientifiques de niveau recherche, publiés ou non, émanant des établissements d'enseignement et de recherche français ou étrangers, des laboratoires publics ou privés. 


\section{Short-term effects of two fungicides on enchytraeid and earthworm communities under field conditions}

Joël Amossé ${ }^{*}$, Sylvain Bart ${ }^{1}$, Alexandre R.R. Péry ${ }^{1}$, Céline Pelosi ${ }^{1}$

${ }^{1}$ UMR ECOSYS, INRA, AgroParisTech, Université Paris-Saclay, 78026, Versailles, France

* Corresponding author: UMR1402 INRA AgroParisTech ECOSYS, Bâtiment 6, RD 10, 78026 Versailles cedex, France. Tel: (+33)1.30.83.36.07; Fax: (+33)1.30.83.32.59. E-mail address: joel.amosse@inra.fr, celine.pelosi@inra.fr

\section{Abstract}

Because of the wide use of pesticides in agriculture, there is still a need of higher-tier field studies to assess ecotoxicological effects of commercial formulations on a wider variety of non-target soil organisms such as soil annelids. We here tested the effects of different concentrations of two

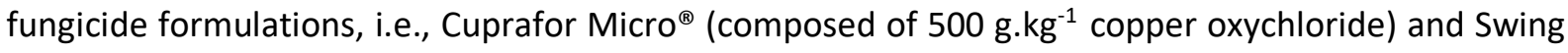

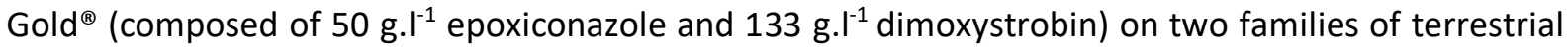
oligochaetes (Lumbricidae and Enchytraeidae) after one month of exposure. We also assessed the feeding activity of soil organisms using the bait lamina method. Along with the feeding activity, the enchytraeid density, diversity and communities were not different in the control and the contaminated plots. By contrast, epigeic earthworms were absent and earthworm diversity and densities of anecic species decreased significantly in the plots contaminated at ten times the recommended dose of the Swing Gold ${ }^{\oplus}$ formulation. The copper fungicide (at 0.75 and $7.5 \mathrm{~kg} \mathrm{Cu}^{-\mathrm{ha}^{-1}}$ ) and the treatment with the pesticide mixture (Cuprafor Micro ${ }^{\circledR}$ at $0.75 \mathrm{~kg} \mathrm{Cu} \cdot \mathrm{ha}^{-1}$ and Swing Gold ${ }^{\circledR}$ at the recommended dose) did not affect Oligochaeta communities compared with the control, except the Shannon index for earthworms in the mixture of both fungicides. Responses of the two annelid families to the tested pesticides were different with higher effects observed on the diversity and the 
community structure of earthworms compared with enchytraeids. This study allowed detecting early changes on oligochaete populations after pesticide application.

Key words: Soil Oligochaeta, Pesticides, Ecotoxicology, Agroecosystems, Feeding activity

\section{Introduction}

The intensification of pesticide use in agriculture is a threat for the environment (Stoate et al., 2001; DeLonge et al., 2016). The resulting loss of biodiversity may impair soil functioning (e.g., nutrient cycling, soil structure) and the related ecosystem services (Altieri, 1999; Tilman et al., 2002). Earthworms and enchytraeids (Annelida: Oligochaeta) are commonly found in a wide range of soils across the world. They respectively belong to the soil macrofauna (body diameter $>2 \mathrm{~mm}$ ) and mesofauna (body diameter between 0.1 and $2 \mathrm{~mm}$ ) (Gobat et al., 2004). Regarding their size, they play key ecological roles in soils at different scales (i.e., mesoscale for enchytraeids and macroscale for earthworms). Earthworms and enchytraeids contribute to the litter fragmentation and organic matter decomposition (Marinissen and Didden, 1997; Edwards, 2004). Moreover, they are involved in soil formation processes by creating soil porosity and enhancing soil aggregation by mixing mineral and organic particles (Topoliantz et al., 2000; Lavelle and Spain, 2001). Both earthworms and enchytraeids have been recognized as indicators of soil quality and soil management (Paoletti, 1999; Pelosi and Römbke, 2016).

While the effects of pesticides on earthworms and enchytraeids are quite well documented under laboratory conditions (short term effects such as earthworm acute toxicity tests OECD 207, 1984; longer term effects such as reproduction tests on earthworms OECD 222, 2004 and enchytraeids OECD 220, 2016; Didden and Römbke, 2001; Amorim et al., 2005; Pelosi et al., 2014), much less is known about these ecotoxicological impacts on annelid diversity and community structure under field conditions. Some authors reported negative effects of pesticides on earthworms in agricultural 
fields (Eijsackers et al., 2005; Prado et al., 2016; Datta et al., 2016). However, other studies found opposite results mainly due to confounding factors, i.e., soil type, sampling season, type of alternative agricultural practices and crops (Lavelle and Spain, 2001; Marwitz et al., 2014). Indeed, several agricultural practices might vary at the same time, making the identification of a causal relationship between exposure to contaminants and ecological damage very challenging (Pelosi et al., 2014). Moreover, very few studies have been carried out with pesticides and enchytraeid populations under natural or semi-field conditions, i.e., Terrestrial Model Ecosystem (TME) (Maraldo et al., 2006; Römbke et al., 2009; Scholz-Starke et al., 2013; Bandow et al., 2016). Bandow et al. (2016) found negative effects of the pyrimethanil fungicide on several enchytraeid species, especially Fridericia connata, using TME. Thus, the enchytraeid response to pesticides under natural conditions has not been well established yet (Didden and Römbke, 2001; Scholz-Starke et al., 2013) and needs to be more investigated. Finally, to our knowledge, only one study investigated the effects of pesticides on both earthworm and enchytraeid densities simultaneously under natural conditions (McColl, 1984).

While laboratory ecotoxicological tests of chemical substances on single species are routinely used, much less is known about the effects of commercial formulations of pesticides on oligochaete (enchytraeid and earthworms) diversity, community structure and the soil functioning under field conditions. Our aim was thus to study the patterns of diversity and community structure of earthworms and enchytraeids in response to pesticide exposure (i.e., two commercial formulations) under field conditions. We made the assumptions that the effects of pesticides on short-term (i.e., one month) on enchytraeid and earthworm communities would be negative and of the same magnitude for both organisms. We also hypothetized that lower density and diversity of oligochaetes would lead to lower soil functioning (i.e., feeding activity). 
We investigated the density, diversity indices and some ecological and functional traits (i.e., ecological categories for earthworms, proportion of $r$-strategists for enchytraeids) of each family. We also explored the relationships between enchytraeid and earthworm populations. We finally assessed the feeding activity of soil organisms using the bait lamina method, making the assumption that lower-bait consumption rates would be observed in plots treated with pesticides. The two commercial formulations of fungicides were Cuprafor Micro $^{\circledR}$ (copper oxychloride, used in organic agriculture) and Swing Gold ${ }^{\circledR}$ (composed of epoxiconazole and dimoxystrobin, used in conventional agriculture).

\section{Material and methods}

\section{Study site and experimental design}

The experiment was conducted and adapted from the ISO standard method for earthworm field studies (ISO $11268-3,2014)$ in a meadow located in Versailles, France $\left(48^{\circ} 48^{\prime} 31^{\prime \prime} \mathrm{N}, 2^{\circ} 05^{\prime} 26^{\prime \prime} \mathrm{E}\right)$ which had not received pesticides for more than 20 years. The climate was oceanic temperate, with a mean annual temperature of $11^{\circ} \mathrm{C}$ and a mean annual rainfall of $660 \mathrm{~mm}$ (weather station at $500 \mathrm{~m}$ from the study site, La lanterne, Versailles). The mean temperature between pesticide application and the sampling period (i.e. one month) was $11.1^{\circ} \mathrm{C}$. The cumulated rainfall during this period was $54 \mathrm{~mm}$. The soil was a deep Luvisol (FAO soil classification) developed on loess. The homogeneity of the physicochemical characteristics in the experimental site was verified by randomly sampling a soil core at seven different locations in the site. The main characteristics of the soil are loam texture (USDA), OM content $11 \%, \mathrm{pH}_{\mathrm{H} 2 \mathrm{O}} 7.5$ and $\mathrm{Cu}_{\text {tot }} 25.2 \mathrm{mg} \cdot \mathrm{kg}^{-1}$. Physicochemical properties of the soil are more described in Bart et al. (2017).

Two commercial formulations of fungicides used in Europe (e-phy 2017 a,b) were tested: Cuprafor Micro ${ }^{\circledR}$ (Industrias Quimicas del Valles, composed of $500 \mathrm{~g} . \mathrm{kg}^{-1}$ copper oxychloride, $\mathrm{Cu}_{2} \mathrm{Cl}(\mathrm{OH})_{3}$ ) and

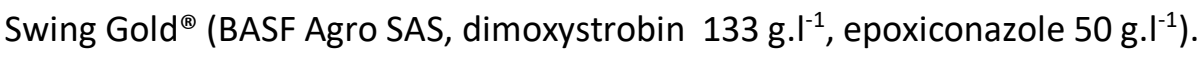


Cuprafor Micro $^{\circledast}$ is used to prevent spore germination by disrupting the enzyme systems of pathogens. It is an inorganic fungicide used as a foliar spray for pest control such as leaf spot and downy mildew (PPDB, 2017). Swing Gold ${ }^{\circledR}$ is a synthetic substance which is mainly used to control late season diseases (e.g. septoria, rusts) of cereals in conventional agriculture. Epoxiconazole (EPX) is a triazole fungicide and a sterol biosynthesis inhibitor with preventative and curative action (PPDB, 2017). Dimoxystrobin (DMX) is a stobilurin fungicide and a respiration inhibitor with protectant, curative and translaminar action.

The experimental trial consisted of four replicates of six treatments randomly located ( 24 plots, 100

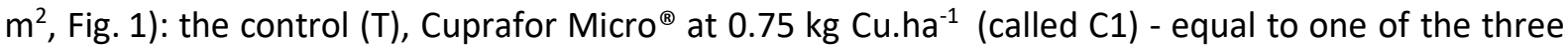
to four copper applications per year in an agronomical context (e-phy 2017a) - and ten times this concentration i.e., $7.5 \mathrm{~kg} \mathrm{Cu} \mathrm{ha}^{-1}$ (called C10), Swing Gold ${ }^{\circledR}$ at one (1.5 I.ha ${ }^{-1}$, called D1) and ten (15 I.ha ${ }^{-1}$, D10) times the recommended dose (e-phy 2017b), and a mixture of Cuprafor Micro ${ }^{\circledR}$ at $0.75 \mathrm{~kg}$ Cu.ha ${ }^{-1}$ and Swing Gold ${ }^{\circledR}$ at the recommended dose (called M). The plots were treated in April 2016 using a manual sprayer (capacity of twenty liters). Before pesticide application, the vegetation was cut as short as possible and the residues were removed with a lawn mower. The pesticides were diluted within eight liters of water and applied homogeneously on each plot. A volume of eight liters of water was also spiked in the control plots.

\section{Soil annelids}

One month after pesticide application (i.e., in May 2016), earthworms were extracted by using an expellant solution of allyl isothiocyanate diluted with isopropanol (propan-2-ol) and water to obtain a $0.1 \mathrm{~g} \mathrm{~L}^{-1}$ solution. In each of the 24 plots, four sampling points were done. For each sampling point, twice $3.2 \mathrm{~L}$ of the expellant solution were poured in a metal frame of $0.16 \mathrm{~m}^{2}$ surface $(0.4 \times 0.4 \mathrm{~m})$ (Pelosi et al., 2009). After twenty minutes during which emerging earthworms were retrieved, a 
block of soil (i.e., $40 \times 40 \times 20 \mathrm{~cm}$ ) was excavated in the same squares and the last earthworms were extracted manually. Earthworms were stored in a $4 \%$ formaldehyde solution. Adult and sub-adult individuals were identified at the species level (Sims and Gerard, 1999). Juveniles were also identified at the species level according to morphological characters of the adults and to the specific form they take in formalin in comparison with that of identified adults. In cases where species-level identification was impossible (e.g., no discrimination characters between juveniles of Aporrectodea longa and Aporrectodea giardi), juvenile individuals were allocated to species proportionally to the number of adults and sub-adults. All individuals were counted, weighted, and classified according to three ecological categories defined by Bouché (1977), i.e., epigeic, endogeic and anecic.

For enchytraeids, four soil cores were sampled in each plot using a split soil corer (diameter of $5 \mathrm{~cm}$ ) at $10 \mathrm{~cm}$ depth. Each sample was transferred separately into a plastic bag and stored at $4^{\circ} \mathrm{C}$. Enchytraeids were extracted using wet funnel extractors under a light from incandescent light bulbs (40 watts). Soil samples were heated up from $17^{\circ} \mathrm{C}$ to $43^{\circ} \mathrm{C}$ on their upper surface for 3 hours (O'Connor, 1955; Kobetičová and Schlaghamerský, 2003). All individuals were kept in Petri dishes with tap water and counted. Adult and sub-adult individuals were identified at the species level under a light microscope (up to 400x magnification) according to the key of Schmelz and Collado (2010). Not Identified (NI) enchytraeids (e.g., dead specimens) were also counted. The total enchytraeid density, the density of each species and the proportion of $r$-strategist species (Graefe and Schmelz, 1999) were determined.

Finally, soil temperature and moisture were checked at the experimental site to ensure earthworm sampling conditions. Soil temperature (i.e., $15.9^{\circ} \mathrm{C}$ in average of all plots) was measured in the field with an electronic digital thermometer at $10 \mathrm{~cm}$ of soil depth. For soil moisture, soil cores were sampled with a metal cylinder ( $5 \mathrm{~cm}$ internal diameter) at two soil depths i.e., $10 \mathrm{~cm}$ for enchytraeids 
(i.e., $25.7 \%$ in average of all plots) and $20 \mathrm{~cm}$ (i.e., $22.6 \%$ ) for earthworms. Soil moisture was then measured in the laboratory after drying soil samples for 72 hours at $105^{\circ} \mathrm{C}$.

\section{Feeding activity}

The feeding activity of soil organisms was measured using the bait lamina method (ISO 18311, 2014). Briefly, PVC sticks (Terra Protecta GmbH, Berlin, Germany) containing 16 apertures, which are $5 \mathrm{~mm}$ apart from each other, were filled with cellulose powder (70\%), finely ground wheat bran (25\%) and activated carbon powder (5\%). In May 2016, in each plot, 16 sticks were inserted in a $4 \times 4$ grid within an area of about $30 \mathrm{~cm} \times 30 \mathrm{~cm}$. We determine the exposure time by regularly screening bait lamina strips inserted close to the study site in order to identify the duration in which at least $10 \%$ of all baits were fed. After 10 days, the sticks were retrieved from the soil and fed (i.e., disappearance of at least half of the organic bait material) or not fed apertures were directly counted. The global rate and the vertical distribution of the feeding activity were calculated.

\section{Statistical analyses}

For each plot, measurement endpoints for the group of annelids (i.e., total density, species density, epigeic, anecic and endogeic density, proportion of $r$-strategist enchytraeids) were calculated from the sum of the four samples and expressed as density (ind. $\mathrm{m}^{-2}$ ). Mean values of each variable were then averaged on the four replicates of each treatment. The differences in diversity indices, i.e., species richness, Shannon and Pielou's evenness, and feeding activity between all treatments were assessed on log transformed data $(\log (x+1))$ using parametric tests (one way ANOVA followed by a multiple comparison Dunnett test, Hothorn et al., 2017 (multcomp.glht)) if the homogeneity of variance (Bartlett-test, Snedecor and Cochran, 1989) and the normality of residuals (Shapiro test) were respected. Non-parametric tests (Kruskal-Wallis test followed by a multiple comparison kruskalmc test, Giraudoux, 2017 (pgirmess.kruskalmc)) were used if these conditions were not respected. At each multiple post-hoc test, adjusted p-values based on Bonferroni's corrections were 
applied (Bland and Altman, 1995). All statistical analyses were done with $n=4$. The level of significance was fixed at $p<0.05$. Minimum Detectable Differences (MDDs) were calculated for key species and ecological groups of earthworms according to Brock et al. (2015). They were expressed as percentage (\% MDD, 4 replicates) of the control after back-transformation of the data.

The correlations between enchytraeid and earthworm variables, and between annelid variables and feeding activity were tested using Pearson or Kendall coefficient of correlation (for normal and nonnormal distribution of the data, respectively). Given the high number of tests, Bonferroni's corrections to $p$-values were also applied. Relationships between earthworm and enchytraeid communities were assessed in the different treatments using Mantel tests (Mantel, 1967) using vegan (Oksanen et al., 2017) on Bray-Curtis dissimilarity transformation matrices ( $p<0.05,23$ permutations). All analyses were carried out with R statistical software (R Development Core Team, 2016).

\section{Results}

\section{Enchytraeids}

A total of 5637 enchytraeids were collected from all plots. The mean density of total enchytraeids varied from 24574 (in C10) to 36733 ind. $\mathrm{m}^{-2}$ (in M) without any significant difference between treatments (Fig. 2 and Table 1). Similarly, no difference was observed for the diversity metrics (i.e., species richness, Shannon index, proportion of $r$-strategists, and evenness) between plots treated with or without pesticides. Species richness was positively correlated $(r=0.348, p$-value $=0.025)$ with the enchytraeid density (Supplementary table 1). A total of 21 enchytraeid species were identified in the six treatments (Table 2). The most abundant species was the $r$-strategist Enchytraeus buchholzi, followed by Fridericia galba and then Fridericia isseli (Table 2). The density of each species was not significantly different between treatments (Table 2). 


\section{Earthworms}

A total of 3274 earthworms were collected from all plots. The mean density of total earthworms ranged from 127 (in D10) to 264 ind. $\mathrm{m}^{-2}$ (in C10) (Fig. 2) and the mean biomass ranged from 48.3 (in D10) to $93.6 \mathrm{~g} \cdot \mathrm{m}^{-2}$ (in C10) (Table 1). Density and biomass of earthworms were highly correlated ( $\mathrm{r}=$ 0.941, $p<0.001$ ). No significant difference was observed between treatments (Table 1). Contrarily, diversity metrics (i.e., species richness, Shannon index and Pielou's evenness) were significantly lower in the D10 than in the control $(\mathrm{T})$ treatments. The same was found for the Shannon index in the $\mathrm{M}$ treatment compared with the control plots. The density and species richness of earthworms were positively correlated $(r=0.340, p$-value $=0.027$ ) (Supplementary table 1 ). A total of 12 earthworm species were identified in the six treatments (Table 3). The highest species richness was recorded in the $\mathrm{T}, \mathrm{C} 10$, and $\mathrm{D} 1$ treatments with respectively 10,11 , and 10 species. The lowest species richness (i.e., 5 species) was recorded in the D10 treatment. The most abundant species was the endogeic Aporrectodea icterica followed by Lumbricus terrestris and then Aporrectodea caliginosa (Table 3).

The occurrence of the different ecological groups differed among treatments (Tables 1 and 3). The density of endogeic earthworms was not significantly different between treatments (Table 1) although $A$. caliginosa species was lower (- $81.4 \% \mathrm{MDD})$ in D10 treatment compared with the control (Table 4). Epigeic earthworms were found in all treatments, except in D10. The anecic density was significantly lower in the D10 treatment compared with the control (Table 1). This can be mainly explained by lower L. terrestris (- $71.1 \% \mathrm{MDD})$ and Aporrectodea longa (- $80.1 \% \mathrm{MDD})$ densities in the D10 treatment than in the control plots (Table 4). The A. longa density was also lower $(-80.2 \%$ MDD) in the mixture treatment compared with the control (Table 4). 
No significant correlation was observed between earthworms and enchytraeid species richness, density and functional groups (ecological categories for earthworms and percentage of $r$-strategists for enchytraeids) (Supplementary table 1). Moreover, mantel tests did not reveal any significant relationship between enchytraeid and earthworm communities in treated and non-treated soils, except a positive relationship between enchytraeid and earthworm communities in C10 ( $r=0.743, p-$ value $=0.042)$ (Supplementary table 2). Earthworm and enchytraeid communities were not different in the control ( $\mathrm{T}$ ) and the other treatments (Supplementary table 3 and 4, respectively).

\section{Feeding activity}

The feeding rate varied from $16.7 \%$ (in C10) to $24.1 \%$ (in C1), but no significant difference was observed between treatments. In the first three centimeters of soil, the feeding rate was higher in C1 compared with the other treatments (Fig. 3). No relationship was found between the density of each annelid families and the feeding activity $(r=0.088, p$-value $=0.551$ for enchytraeids; $r=-0.227 p$ value $=0.123$ for earthworms) .

\section{Discussion}

\section{Enchytraeid sensitivity to the tested fungicides}

Soil annelid sensitivity to chemicals is generally considered as useful information to assess the effect of pesticides on the living compartment of the soil (Didden and Römbke, 2001). We here found that enchytraeids were not affected by Cuprafor Micro ${ }^{\circledR}$ and Swing Gold ${ }^{\circledR}$ whatever the fungicide concentrations (one and ten times the doses). For the commercial formulation of Swing Gold ${ }^{\circledR}$, Bart et al. (2017) reported a LC50 (Lethal Concentration causing 50\% mortality) at 11 times the recommended dose (RD) for Enchytraeus albidus (Henle, 1837) in the same soil (from the same experimental site), which is higher than the highest dose applied in our field study (10 times the recommended dose). The field conditions (i.e. vegetation cover playing a barrier role for pesticide migration into the soil) could explain why no differences were observed between the control and the 
plots treated with the Swing Gold ${ }^{\circledR}$. Similarly, McColl (1984) found that enchytraeids were not affected by the nematicide oxamyl (12.7 I a.i ha ${ }^{-1}$, equal to 85 times the recommended dose on maize, e-phy 2017c) after sampling every month for one year in a mixed ryegrass-clover. In our study, enchytraeid species densities were not significantly different in plots treated with pesticides compared to the control. This was not always the case as reported in previous studies (Moser et al., 2007; Römbke et al., 2009). Under field conditions (i.e., in a grassland), Römbke et al. (2009) found a change in community pattern and lower enchytraeid density (11 213 vs. 8690 ind. $\mathrm{m}^{-2}$ ) after two applications (interval of fourtheen days) of a mixture of the fungicide benomyl ( $8 \mathrm{~kg} \cdot \mathrm{ha}^{-1}$, equal to 40 times the recommended dose on wheat, e-phy 2017d) and the insecticide chlorpyrifos (900 g.ha-1 ${ }^{-1}$. They found that densities of the genera Buchholzia (1 902 vs. 1501 ind.m²), Henlea (301 vs. 198 ind. $\mathrm{m}^{-2}$ ), Fridericia (3 274 vs. 2452 ind. $\mathrm{m}^{-2}$ ), and Marionina (2 435 vs. 1860 ind. $\mathrm{m}^{-2}$ ) were significantly reduced one month after pesticide application. Similarly, Moser et al. (2007) found that the fungicide carbendazim at $13 \mathrm{~kg} \cdot \mathrm{ha}^{-1}$ (equal to 65 times the recommended dose on wheat, e-phy 2017e) significantly affected enchytraeids four weeks after pesticide application, especially the genera Fridericia and Henlea.

Concerning the copper fungicide, our results are in accordance with Bart et al. (2017) who showed that Cuprafor Micro $^{\circledast}$ did not induce lethal effect of enchytraeids (E. albidus) even at high concentration (5 $000 \mathrm{mg} \mathrm{Cu} . \mathrm{kg}^{-1}$ dry soil) after 14 days of exposure in laboratory. Maraldo et al.

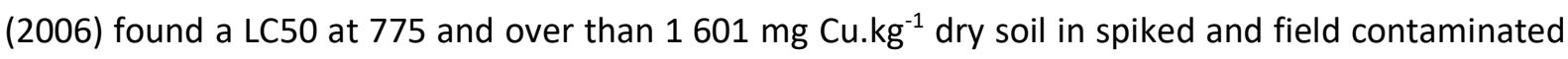
soils under laboratory conditions, respectively. These differences with Bart et al. (2017)'s results could be explained by the soil type (loamy in Bart et al., 2017 vs. sandy loam in Maraldo et al., 2006), the species tested in laboratory (E. albidus in Bart et al., 2017 vs. E. crypticus (Westheide \& Graefe, 1992) in Maraldo et al., 2006), and the tested copper formulations $\left(\mathrm{Cu}_{2} \mathrm{Cl}(\mathrm{OH})_{3}\right.$ in Bart et al., 2017 vs. $\mathrm{CuSO}_{4}$ in Maraldo et al., 2006). Under field conditions, some studies reported lower enchytraeid

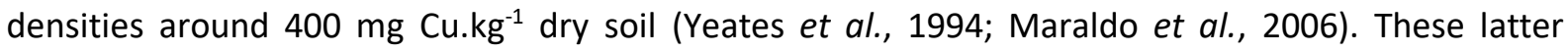


results could explain why we did not observe any difference in plots treated with copper, with a maximum dose applied at $7.5 \mathrm{~kg} \cdot \mathrm{ha}^{-1}$ (equal to $10 \mathrm{mg} \mathrm{Cu} \cdot \mathrm{kg}^{-1}$ dry soil if we consider the ten first soil centimeters). Moreover, Maraldo et al. (2006) observed that the diversity ( 2 to 9 species), the total number ( 3 to 67 individuals) and the species composition of enchytraeids (especially Fridericia connata, Bretsher, 1902, Achaeta bohemica, Enchytronia parva, Marionina communis, and F. galba)

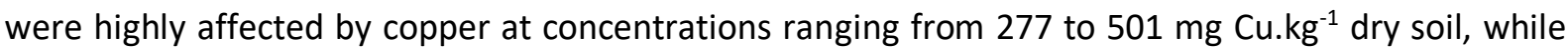
other species such as E. buchholzi ( $r$-strategist) and Fredericia ratzeli (Eisen, 1872) were found to high

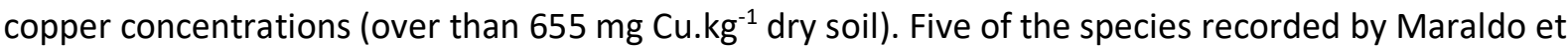
al. (2016) were identified in our study (i.e., A. bohemica, En. parva, M. communis, F. galba and E. buchholzi) and all of them were not significantly affected by copper application.

Based on EFSA's opinion (EFSA PPR Panel, 2017), we found that effects of tested pesticides on enchytraeids are negligible (i.e., reduction up to $10 \%$ ) to small (i.e., reduction above $10 \%$ and below $35 \%$ four weeks after pesticide application) compared with the control. The magnitude of effects is considered to allow for internal recovery of enchytraeids populations and would have no consequences on the provision of ecosystem services (EFSA PPR Panel, 2017).

\section{Earthworm sensitivity to the tested fungicides}

The study of short term effects (i.e., one month) of pesticides on annelids allows detecting early changes on oligochaete populations and to compare results obtained under field and laboratory conditions. For earthworms, no significant effects were observed in the plots treated with the pesticides except with the Swing Gold $^{\circledR}$ formulation at ten times the recommended dose. Less anecics - especially L. terrestris - were found in this treatment than in the control plots. It is worthwhile to note that numerous dead anecic and endogeic earthworms were observed in the D10 treatment few days after pesticide application (pers. obs., Fig. 4), showing the rapid lethal effect of the Swing Gold ${ }^{\circledR}$ on earthworms. Moreover, although the differences were not statistically different 
but partly shown with \% MDDs, epigeic and some endogeic earthworms species (i.e., L. castaneus and $A$. caliginosa, Savigny, 1826) were negatively affected by the Swing Gold ${ }^{\circledR}$ formulation at ten times the recommended dose. In the literature, earthworms, and especially epigeics and anecics, are already shown to be directly affected by pesticides (Pelosi et al., 2014) because they are directly exposed to them through their feeding activity at the soil surface (Edwards and Bohlen, 1996). Moreover, the results found in the present study are in accordance with the LC50 of 6.3 times the recommended dose calculated by Bart et al. (2017) for the species A. caliginosa under laboratory conditions. For the fungicide benomyl $\left(1.0 \mathrm{~kg}\right.$ a.i ha- ${ }^{-1}$, equal to 5 times the recommended dose on wheat, e-phy 2017c) studied under field conditions (i.e., in a grassland), Christensen and Mather (2004) found a significant increase in earthworm migration two days after the application, especially L. terrestris, A. longa, and A. caliginosa species. These results match well with our observations because the three species listed above were among the most affected by the Swing Gold ${ }^{\circledR}$ formulation at ten times the recommended dose. Similarly, Schnug et al. (2015) showed that the total density of earthworms and in particular the density of $A$. caliginosa significantly decreased one month after the application of the fungicide picoxystrobin at concentrations known to inhibit from 10 to $90 \%$ the cocoon production of Eisenia fetida (Savigny, 1926) (i.e. from 250.9 to $592.9 \mu \mathrm{mol} . \mathrm{m}^{-2}$ ). They also reported that the mixture of three biocides (the insecticide esfenvalerate, the fungicide picoxystrobin, and the bactericide triclosan) affected earthworm density, especially A. caliginosa and Aporrectodea rosea (Savigny, 1826) species densities. This trend was not observed in our study with the mixture of both pesticides, except the lower Shannon diversity index compared with the control plots. This can be mainly explained by lower densities of L. castaneus and A. longa species in this treatment compared to the control plots. In our case, binary (D treatment with DMX and EPX) and tertiary (M treatment with DMX, EPX and copper) mixtures of pesticides could be considered. The tested mixtures could have additive or synergistic effects on oligochaetes. For example, LC50 of Eisenia foetida with the single active substance of dimoxystrobin was $23.65 \mathrm{mg} \mathrm{kg}^{-1}$ (moderate 
effects) (PPDB, 2017). While, the LC50 of Eisenia foetida with the dimoxystrobin in the Swing Gold ${ }^{\circledR}$ formulation was $3.35 \mathrm{mg} \mathrm{SA} / \mathrm{kg}$ (higher effect; Agritox, 2017).

Concerning the copper fungicide, no effect was observed on earthworm populations. Studies dealing with the effects of copper on earthworms showed contrasted results (Van Zwieten et al., 2004; Owojori and Reinecke, 2010). This could be mainly explained by the mode of contamination (i.e., mine soils, spiked soils) and the number of tested contaminants (i.e., one versus several heavy metals) (Spurgeon and Hopkin, 1999; Eijsackers et al., 2005; Tisher, 2008). These discrepancies may hinder the risk assessment linked to the use of copper on soil annelids. For example, Van Zwieten et al. (2004) investigated earthworm communities in two avocado orchards (New South Wales, Australia) and found a negative relationship between earthworm density and the long-term contamination of soils by $\mathrm{Cu}$ and $\mathrm{Zn}$. They found from 155 to less than 1 earthworm per square meter in soil with 29 to $269 \mathrm{mg} \mathrm{Cu} \cdot \mathrm{kg}^{-1}$ dry soil, respectively. Conversely, also under field conditions, Owojori and Reinecke (2010) did not found any significant effect on earthworms twenty days after an

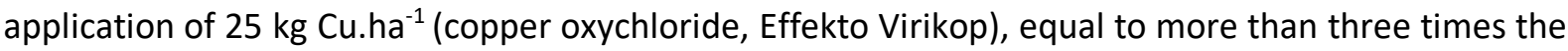
maximum dose applied in our study site. These studies highlight that the effects of copper on soil biota are sometimes not immediate but can appear after several years of applications and accumulation in the soil. However, under controlled conditions Eijsackers et al. (2005) and Bart et al. (2017) showed, a significant decrease in biomass for the species $A$. caliginosa at 50 and $60 \mathrm{mg}$ Cu. $\mathrm{kg}^{-1}$ dry soil after fourteen and twenty days of exposure, respectively. According to the literature (Owojori and Reinecke, 2010) and our results, we assume that copper at the tested concentrations had no short-term impact on oligochaeta populations.

Based on EFSA's opinion (EFSA PPR Panel, 2017) and the percentage of MDD (Brock et al., 2015), we found medium to large effects (between 50 and $70 \%$ for the anecic density, and between 70 and 90 $\%$ for the earthworm species L. terrestris, A. longa and A. caliginosa) of the Swing Gold ${ }^{\circledR}$ at ten times 
the recommended dose on earthworms. For magnitude of effects higher than $65 \%$, this would probably not result in internal recovery in relevant time frame (i.e., six months) and could have consequences on the provision of ecosystem services (EFSA PPR Panel, 2017).

\section{Relationships between Oligochaeta and feeding activity}

In our study, the soil temperature and the soil moisture were close to optimal conditions (Puurtinen and Martikainen, 1997; Booth et al., 2000) for the development of earthworms (i.e., $15,9^{\circ} \mathrm{C}$ and soil water content of $22,6 \%$ ) and enchytraeids (i.e., $15,9^{\circ} \mathrm{C}$ and soil water content of $25,7 \%$ ). Moreover, earthworm (i.e., mean of 213 ind. $\mathrm{m}^{-2}$ ) and enchytraeid (i.e., mean of 29905 ind. $\mathrm{m}^{-2}$ ) densities were in accordance with previous findings in grasslands (Beylich and Graefe, 2012; Domínguez and Bedano, 2016) and with ISO recommendations for earthworm field studies (i.e., > 100 earthworms. $\mathrm{m}^{-2}$, ISO 11268-3, 2014). For example, Beylich and Graefe (2012) found between 91 to 886 earthworms. $\mathrm{m}^{-2}$ and between 9218 and 75274 enchytraeids. $\mathrm{m}^{-2}$ from twelve German grassland sites. They also studied earthworms and enchytraeids densities from seventeen cropland sites and found densities varying between 0 to 783 earthworms. $\mathrm{m}^{-2}$ and between 2037 and 100607 enchytraeids. $\mathrm{m}^{-2}$. Because enchytraeids and earthworms have close habitats, interactions may occur, especially competition for food resources (Karaban and Uvarov, 2014; Domínguez and Bedano, 2016). However, no significant relationships for density, community structure and diversity were found between earthworms and enchytraeids in treated and non-treated soils. Similarly, Beylich and Graefe (2012) highlighted that the density of both families was not significantly correlated in various land uses: forest, wet grassland, grassland, and cropland. Under controlled conditions, Karaban and Uvarov (2014) reported that the inoculation of two individuals of the epigeic species Lumbricus rubellus negatively affected enchytraeid number (from 255 to 204 individuals per experimental unit) and especially litter enchytraeids (species not specified), which nearly disappeared. By contrast, positive effects of two A. caliginosa - an endogeic earthworm species - were observed on enchytraeid number (from 255 to 477 individuals per experimental unit) mainly explained by non- 
trophic relationships (i.e. burrowing activity, cast and mucus production). In our study, enchytraeid density, diversity and community structure did not change after pesticide application, even in the Swing Gold treatment (in D10) where lower density of anecics and the absence of epigeics were recorded. This suggested that no habitat competition occurred between earthworms and enchytraeids.

Concerning the feeding rate, few studies reported that pesticides such as glyphosate (an herbicide), chlorpyrifos or dimethoate (an insecticide) at recommended doses reduced the feeding activity under field conditions (Casabé et al., 2007; Santos et al., 2011). By contrast, other studies concluded that glyphosate or thiram (a fungicide) did not reduce the feeding activity and was even higher compared to the control (Larink and Sommer, 2002; Santos et al., 2011). Although the feeding rate was not different between treatments in our study, this trend was also observed in C1 where a higher feeding activity in the three first centimeters of soil was recorded, compared to the other treatments. Numerous enchytraeids were observed in the bait lamina apertures (pers. obs.) in treated and non-treated soils after retrieving them from the soil. In accordance with Helling et al. (1998), enchytraeids could be therefore considered as among the main consumers of the baits in the topsoil. Topoliantz et al. (2000) also explained that enchytraeids may increase their activities when earthworm density is low. These small but numerous soil organisms could therefore maintain a biological activity and perform soil functions when earthworms are absent.

Our results showed that enchytraeid species were less affected than some earthworm species by the Swing Gold ${ }^{\circledR}$ formulation. This finding is in accordance with the review made by Jarratt and Thompson (2009) who reported in some cases similar but generally a lower sensitivity of enchytraeids than earthworms to pesticides. For example, Leitão et al. (2014), working under laboratory conditions with a natural soil treated with the fungicide azoxystrobin, found a EC50 (Effective Concentration reducing $50 \%$ of the reproduction) of $42.0 \mathrm{mg}$ a.i. $\mathrm{kg}^{-1} \mathrm{dw}$ soil for 
the enchytraeid species E. crypticus and $31.1 \mathrm{mg}$ a.i. $\mathrm{kg}^{-1} \mathrm{dw}$ soil for the earthworm species Eisenia andrei (Bouché, 1972). However, Jarratt and Thompson (2009) pinpointed the difficulty to accurately compare the sensitivity of enchytraeids and earthworms to chemicals using the existing literature due to confounding factors (e.g. exposure duration, doses, soil type, soil tillage, fertilization). Moreover, the sensitivity of enchytraeids and earthworms to pesticides is species-specific and it is thus difficult to conclude if one soil annelid family is more sensitive than the other. For example, Frampton et al. (2006) studied the soil fauna (e.g., earthworms, collembolan, enchytraeids, nematodes) species sensitivity to pesticides from a large number of publications including several ecotoxicological endpoints (e.g., LC50, No Observed Effect Concentration). They found that the enchytraeid species F. ratzeli and E. albidus were less sensitive than the earthworm species E. fetida, E. andrei and $L$. rubellus to the fungicide carbendazim. Conversely, the enchytraeid Enchytraeus coronatus (Nielsen and Christensen, 1959) was more sensitive to this pesticide than the earthworm species listed above.

\section{Conclusion}

The risk assessment of pesticide use is generally performed under laboratory conditions and not in natura. The strength of our study is to use various pesticide exposure conditions (i.e., one and ten times the recommended dose, mixture) and similar environmental field conditions for treated and non-treated plots, thus reducing confounding factors. Our study revealed contrasting patterns among annelid groups (i.e., earthworms and enchytraeids) in response to pesticide exposure and supports the idea that pesticides used in Europe and in the world can affect soil fauna communities on the short-term (i.e., one month). Moreover, we showed that the mixture of pesticides could have synergistic effects on soil organisms (i.e., lower Shannon index for earthworms) compared to the single use of the tested fungicides under field conditions. We also found that some oligochaete species were more affected than others by pesticides, especially the anecic earthworm Lumbricus terrestris. Longer-term sampling (e.g. after six and twelve months) would be needed to study annelid 
community dynamics (e.g. earthworm recovery) as suggested in the ISO norm for earthworm field studies. It would also be useful to study other non-target animals groups (e.g. microarthropods) and to measure other functional endpoints (e.g. organic matter decomposition, soil structuration) for a better assessment of pesticide effects on the biodiversity and the soil functioning. This study conducted under field conditions is a first step towards the environmental risk assessment of commercial formulations of pesticides.

\section{Acknowledgments}

This study was funded by ANSES (French Agency for Food, Environmental and Occupational Health \& Safety), which provided a post-doctoral grant to Joël Amossé. We greatly thank Franck Brulle (ANSES), Arnaud Conrad (ANSES), Jean-Pierre Pétraud and Jodie Thénard (INRA) for their useful advice on the experimental design. We also thank Yannick Bayona (ANSES) for the calculations of MDDs. We thank Christophe Montagnier and Arnaud Huré (experimental unity, INRA), Marc Hanrio and Florent Viala (park department, INRA) for the rental and the mowing of the meadow before pesticide application. We greatly thank Gergely Boros for enchytraeid species validation and Estelle Chan for earthworm identification. We also thank Sébastien Breuil for soil pollution and many other colleagues of UMR ECOSYS for soil and soil fauna sampling. We would like to thank Anne Cardoso for thorough editorial advice in English. We also thank the IDEX Paris-Saclay, which funded the "IDI 2015" project (ANR-11-IDEX-0003-02) and provided half-funded PhD scolarships for Sylvain Bart. Authors thank the two reviewers for their careful reading and their helpful suggestions, which contributed to improving the quality of the manuscript.

\section{Compliance with Ethical Standards}

Funding: This study was funded by ANSES (French Agency for Food, Environmental and Occupational Health \& Safety) (grant agreement CRD-2015-23_PPV15). 
Conflict of interest: The authors (Joël Amossé, Sylvain Bart, Alexandre R.R. Péry, and Céline Pelosi) declare that they have no conflict of interest.

Ethical approval: All applicable international, national, and/or institutional guidelines for the care and use of animals were followed.

\section{References}

Altieri MA (1999) The ecological role of biodiversity in agroecosystems. Agric Ecosyst Environ 74:1931

Amorim MJB, Römbke J, Soares AMVM (2005) Avoidance behaviour of Enchytraeus albidus: Effects of Benomyl, Carbendazim, phenmedipham and different soil types. Chemosphere 59:501-510

Bandow C, Ling Ng E, Schmelz RM, Paulo Sousa J, Römbke J (2016) A TME study with the fungicide pyrimethanil combined with different moisture regimes: effects on enchytraeids. Ecotoxicology $25: 213-224$

Bart S, Laurent C, Pery ARR, Pelosi C (2017) Difference in sensitivity between earthworms and enchytraeids exposed to two commercial fungicides. Ecotoxicol Environ Saf 140:177-184

Beylich A, Graefe U (2012) Relationships between microannelid and earthworm activity. In: Schrader S, Schmelz RM (ed) Newsletter on Enchytraeidae, 12, Landbauforschung, vTI Agriculture and Forestry Research, Special Issue 357. Thünen-Institut, Braunschweig, pp 1-12

Bland JM, Altman DG (1995) Multiple significance tests - the Bonferroni method, Brit Med J 310:170 
Booth LH, Heppelthwaite V, McGlinchy A (2000) The effect of environmental parameters on growth, cholinersterase activity and glutathione S-transferase activity in the earthworm (Aporrectodea caliginosa). Biomarkers 5:46-55

Bouché MB (1977) Stratégies Lombriciennes. In: Lohm U, Persson T (ed) Soil organisms as components of ecosystems. Stockholm, pp 122-132

Brock TCM, Hammers-Wirtz M, Hommen-Writz M, Hommen U, Preuss TG, Ratte H-T, Roessink I, Strauss T, Van den Brink PJ (2015) The minimum detectable difference (MDD) and the interpretation of treatment-related effects of pesticides in experimental ecosystems. Environ Sci Pollut Res 22:1160-1174

Casabé N, Piola L, Fuchs J, Oneto ML, Pamparato L, Basack S, Giménez R, Massaro R, Papa JC, Kesten E (2007) Ecotoxicological assessment of the effects of glyphosate and chlorpyrifos in an Argentine soya field. J Soils Sediments 7(4):232 - 239

Christensen OM, Mather JG (2004) Pesticide-induced surface migration by lumbricid earthworms in grassland: life-stage and species differences. Ecotoxicol Environ Saf 57:89-99

Datta S, Singh J, Singh S, Singh J (2016) Earthworms, pesticides and sustainable agriculture: a review. Environ Sci Pollut Res 23:8227-8243

DeLonge MS, Miles A, Carlisle L (2016) Investing in the transition to sustainable agriculture. Environ Sci Policy 55:266-273 
Didden WAM, Römbke J (2001) Enchytraeids as indicator organisms for chemical stress in terrestrial ecosystems. Ecotoxicol Environ Saf 50:25-43

Domínguez A, Bedano JC (2016) Earthworm and enchytraeid co-occurrence pattern in organic and conventional farming. Soil Science 181(3/4):148-156

Edwards CA (2004) Earthworm ecology, 2nd edn. CRC, Boca Raton

Edwards CA, Bohlen PJ (1996) Biology and ecology of earthworms, 3rd edn. Chapman \& Hall, London

EFSA PPR Panel (EFSA Panel on Plant Protection Products and their Residues), Ockleford C, Adriaanse P, Berny $P$, Brock T, Duquesne S, Grilli S, Hernandez-Jerez AF, Bennekou SH, Klein M, Kuhl T, Laskowski R, Machera K, Pelkonen O, Pieper S, Stemmer M, Sundh I, Teodorovic I, Tiktak A, Topping CJ, Wolterink G, Craig P, de Jong F, Manachini B, Sousa P, Swarowsky K, Auteri D, Arena M and Rob S (2017) Scientific Opinion addressing the state of the science on risk assessment of plant protection products for in-soil organisms. EFSA Journal 2017;15(2):4690, 225 pp. doi:10.2903/j. efsa.2017.4690

Eijsackers H, Beneke P, Maboeta M, Louw JPE, Reinecke AJ (2005) The implications of copper fungicide usage in vineyards for earthworm activity and resulting sustainable soil quality. Ecotoxicol Environ Saf 62:99-111

Frampton GF, Jänsch S, Scott-Fordsmand JJ, Römbke J, Van den Brink PJ (2006) Effects of pesticides on soil invertebrates in laboratory studies: a review and analysis using pesticides sensitivity distributions. Environ Toxicol Chem 25(9):2480-2489 
Gobat J-M, Aragno M, Matthey W (2004) The living soil, fundamentals of soil science and soil biology. Science Publishers, Enfield

Graefe U, Schmelz RM (1999) Indicator values, strategy types and life forms of terrestrial Enchytraeidae and other microannelids. In: Schmelz RM, Sühlo K (ed), Newsletter on Enchytraeidae, 6. Universitätsverlag Rasch, Osnabrück, pp 59-67

Helling B, Pfeiff G, Larink O (1998) A comparison of feeding activity of collembolan and enchytraeid in laboratory studies using the bait-lamina test. Appl Soil Ecol 7:207-212

Hothorn T, Bretz F, Westfall P, Heiberger RM, Schetzenmeister A, Scheibe S (2017) multcomp: Simultaneaous Inference in General Parametric Models, R package version 1.4-7

ISO (International Organisation for Standardization) (2014) Soil quality: effects of pollutants on earthworms Part 3: guidance on the determination of effects in field situations, ISO 11268-3. Genève

ISO (International Organisation for Standardization) (2014) Soil quality: method for testing effects of soil contaminants on the feeding activity of soil dwelling organisms - Bait-lamina test, ISO 18311. Genève

Jarratt N, Thompson H (2009) Comparison between the sensitivity of enchytraeids and Lumbricidae to chemicals, in particular plant protection products. Final report CFT/EFSA/PPR/2008/01, EFSA (European Food Safety Authority) Supporting Publications, York 
Karaban K, Uvarov AV (2014) Non-trophic effects of earthworms on enchytraeids: an experimental investigation. Soil Biol Biochem 73:84-92

Kobetičová K, Schlaghamerský J (2003) On the efficiency of three schemes of enchytraeid wet funnel extraction. In: Didden W, van Vliet P (ed) Newsletter on Enchytraeidae, 8, Wageningen University, Wageningen, pp 25-31

Larink O, Sommer R (2002) Influence of coated seeds on soil organisms tested on bait lamina. Europ J Soil Biol 38(3-4):287-290

Lavelle P, Spain AV (2001) Soil Ecology. Kluwer Academic Publishers, Dordrecht

Leitão S, Cerejeira MJ, Van den Brink PJ, Sousa JP (2014) Effects of azoxystrobin, chlorothalonil, and ethoprophos on the reproduction of three terrestrial invertebrates using a natural Mediterranean soil. Appl Soil Ecol 76:124-13

Mantel N (1967) Detection of disease clustering and a generalized regression approach, Cancer Res $27: 209-220$

Marinissen JCY, Didden WAM (1997) Influence of the enchytraeid worm Buchholzia appendiculata on aggregate formation and organic matter decomposition. Soil Biol Biochem 29:387-390

Maraldo K, Christensen B, Strandberg B, Holmstrup M (2006) Effects of copper on enchytraeids in the field under differing soil moisture regimes. Environ Toxicol Chem 25(2):604-612 
Marwitz A, Ladewig E, Märländer B (2014) Response of soil biological activity to common herbicide strategies insugar beet cultivation. Europ J Agronomy 54:97- 106

McColl HP (1984) Nematicides and field population of enchytraeids and earthworms. Soil Biol Biochem 16(2):139-143

Moser T, Römbke J, Schallnass H-J, Van Gestel CAM (2007) The use of the multivariate Principal Response Curve (PRC) for community level analysis: a case study on the effects of carbendazim on enchytraeids in Terrestrial Model Ecosystems (TME). Ecotoxicology 16:573-583

OECD (1984) Guideline for the testing of chemicals. No. 207. Earthworm, acute toxicity tests. OECD Publishing, Paris

OECD (2004) Guideline for the testing of chemicals. No. 222. Earthworm reproduction test (Eisenia fetida/Eisenia andrei). OECD Publishing, Paris

OECD (2016) Guideline for the testing of chemicals. No. 220. Enchytraeid reproduction test. OECD Publishing, Paris

O'Connor FB (1955) Extraction of enchytraeid worms from a coniferous forest soil. Nature 175:815816

Oksanen J, Blanchet FG, Kindt R, Legendre P, O'Hara RG, Simpson GL, Solymos P, Stevens MHH, Wagner H (2015) vegan: community ecology package, R package version 2.4-4 
Puurtinen HM, Martikainen EAT (1997) Effect of soil moisture on pesticide toxicity to an enchytraeid worm, Enchytraeus sp. Arch Environ Contam Toxicol 33:34-41

Owojori OJ, Reinecke AJ (2010) Effects of natural (flooding and drought) and anthropogenic (copper and salinity) stressors on the earthworm Aporrectodea caliginosa under field conditions. Appl Soil Ecol 44:156-163

Paoletti MG (1999) The role of earthworms for assessment of sustainability and as bioindicators. Agric Ecosyst Environ 74(1-3):137-155

Pelosi C, Barot S, Capowiez Y, Hedde M, Vandenbulcke F (2014) Pesticides and earthworms. A review. Agron Sustainable Dev 34:199-228

Pelosi C, Bertrand M, Roger-Estrade J (2009) Earthworm community in conventional, organic and notilled with living mulch cropping systems. Agron Sustainable Dev 29:287-295

Pelosi C, Römbke, J (2016) Are Enchytraeidae (Oligochaeta, Annelida) good indicators of agricultural management practices? Soil Biol Biochem 100:255-263

Prado B, Gastelum Strozzi A, Huerta E, Duwig C, Zamora O, Delmas P, Casasola D, Márquez J (2016) 2,4-D mobility in clay soils: impact of macrofauna abundance on soil porosity. Geoderma 279:87-96

R Development Core Team (2016) R: a Language and environment for statistical computing. R Foundation for Statistical Computing, Vienna 
Römbke J, Schmelz RM, Knaebe S (2009) Field studies for the assessment of pesticides with soil mesofauna, in particular enchytraeids, mites and nematodes: design and first results. Soil Org $81: 237-264$

Santos MJG, Morgado R, Ferreira NGC, Soares AMVM, Loureiro S (2011) Evaluation of the joint effect of glyphosate and dimethoate using a small-scale terrestrial ecosystem. Ecotoxicol Environ Saf 74:1994-2001

Schmelz RM, Collado R (2010) A guide to European terrestrial and freshwater species of Enchytraeidae (Oligochaeta). Soil Org 82(1):1-176

Schnug L, Ergon T, Jakob L, Scott-Fordsmand JJ, Joner EJ, Leinaas HP (2015) Responses of earthworms to repeated exposure to three biocides applied singly and as a mixture in an agricultural field. Sci Tot Environ 505:223-235

Scholz-Starke B, Beylich A, Moser T, Nikolakis A, Rumpler N, Schäffer A, Theißen B, Toschki A, RoßNickoll M (2013) The response of soil organism communities to the application of the insecticide lindane in terrestrial model ecosystems. Ecotoxicology 22:339-362

Sims RW, Gerard BM (1999) Earthworms: notes for the identification of British species, revised eds. Field Studies Council, Shrewsbury

Snedecor G W, Cochran WG (1989) Statistical Methods, $8^{\text {th }}$ ed. lowa State University Press, Ames 
Spurgeon DJ, Hopkins SP (1999) Seasonal variation in the abundancelbiomass and biodiversity of earthworms in soils contaminated with metal emissions from a primary smelting works. J Appl Ecol $36: 173-183$

Stoate C, Boatman ND, Borralho RJ, Carvalho CR, Snoo GRD, Eden P (2001) Ecological impacts of arable intensification in Europe. J Environ Manage 63(4):337-365.

Tilman D, Cassman KG, Matson PA, Naylor R, Polasky S (2002) Agricultural sustainability and intensive production practices. Nature 418(6898):671-677

Tisher S (2008) Lumbricidae communities in soil monitoring sites differently managed and polluted with heavy metals. Pol J Ecol 56(4):635-646

Topoliantz S, Ponge J-F, Viaux P (2000) Earthworm and enchytraeid activity under different arable farming systems, as exemplified by biogenic structures. Plant Soil 225:39-51

United States Department of Agriculture (USDA) (1975) Soil taxonomy: a basic system of soil classification for making and interpreting soil surveys. Natural Resources Conservation Service, Washington DC

Van Zwieten L, Rust J, Kingston T, Merrington G, Morris S (2004) Influence of copper fungicide residues on occurrence of earthworms in avocado orchard soils. Sci Tot Environ 329:29-41

Yeates GW, Orchard VA, Speir TW, Hunt JL, Hermans MCC (1994) Impact of pasture contamination by copper, chromium, arsenic timber preservative on soil biological activity. Biol Fertil Soils 18:200-208 


\section{Web references}

Agritox, 2017. 〈http://www.agritox.anses.fr/php/sa.php?Sa=1519〉.

e-phy 2017a. 〈http://e-phy.agriculture.gouv.fr/spe/9400346-10024578.htm).

e-phy 2017b._http://e-phy.agriculture.gouv.fr/spe/2090171-1559.htm).

e-phy 2017c. 〈http://e-phy.agriculture.gouv.fr/mata/642.htm).

e-phy 2017d. 〈http://e-phy.agriculture.gouv.fr/spe/6900098-3540.htm).

e-phy 2017e. 〈http://e-phy.agriculture.gouv.fr/spe/8000449-6898.htm).

PPDB, 2017. 〈https://sitem.herts.ac.uk/aeru/ppdb/en〉. 


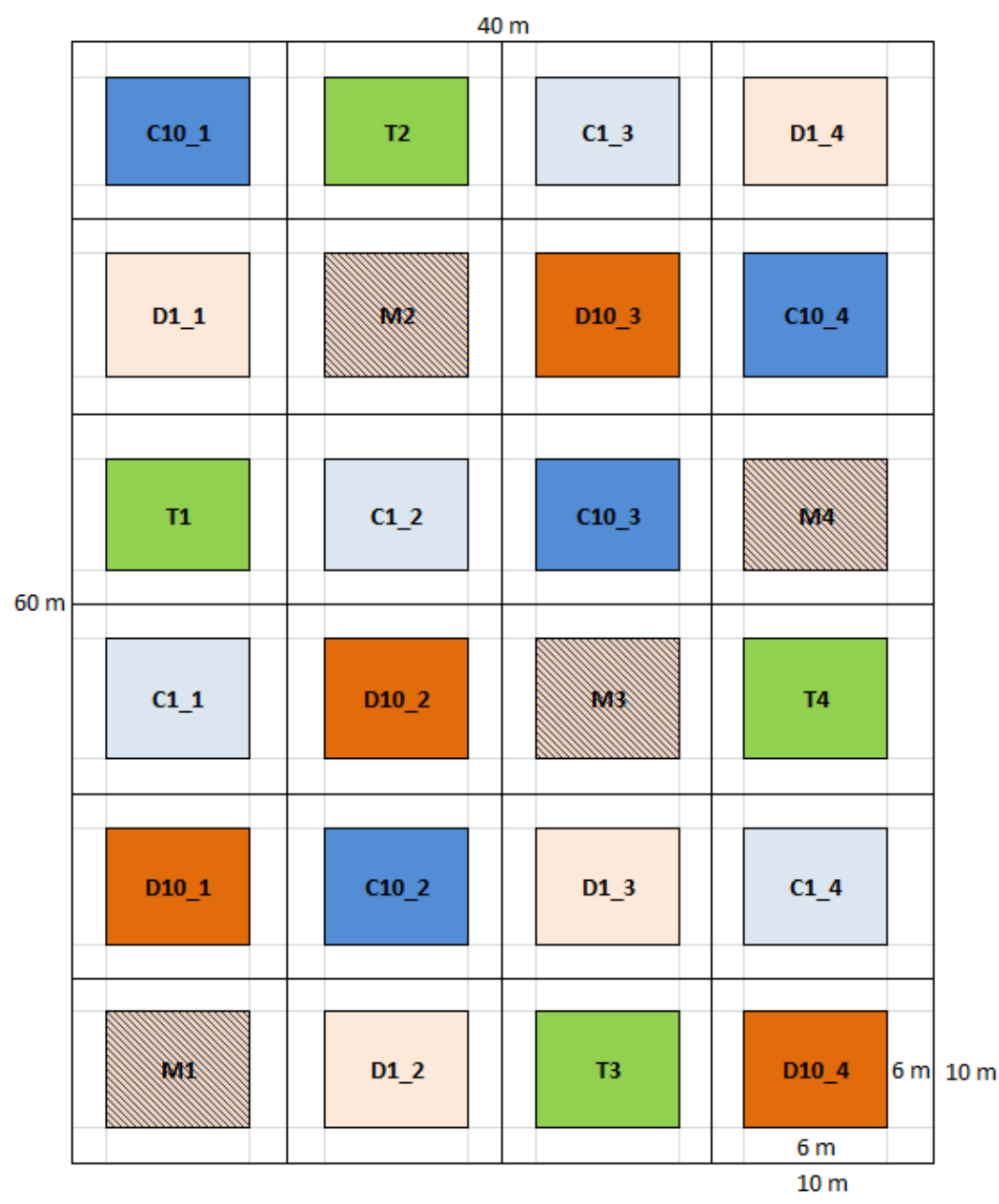

Fig. 1 Field experimental design with the six modalities (four replicates). Treatments are: control (T, green),

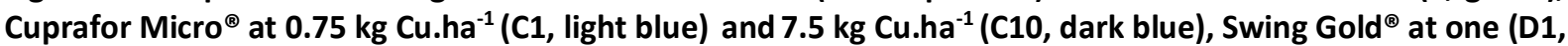
light orange) and at ten (D10, dark orange) times the recommended dose, and a mixture of Cuprafor Micro ${ }^{\circledR}$

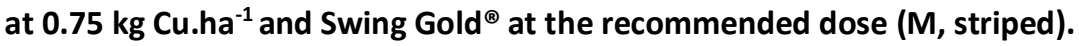



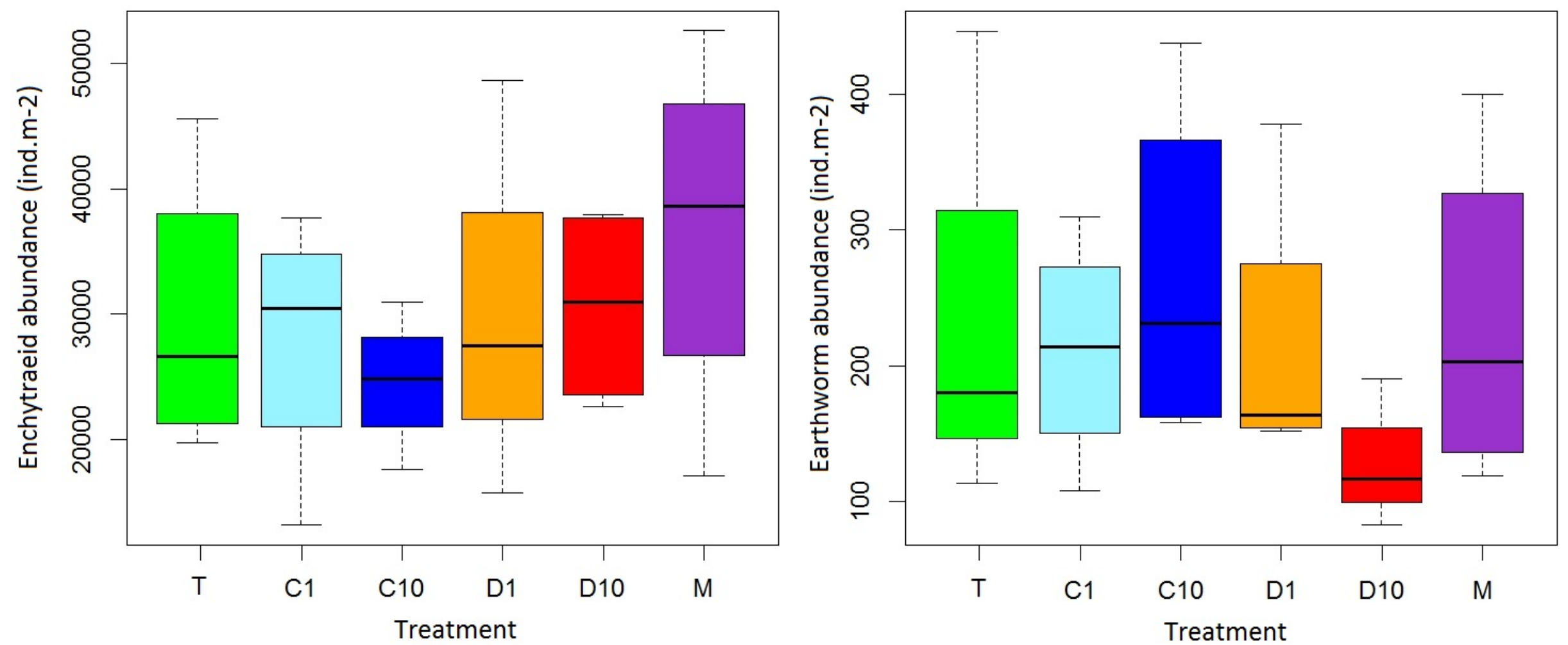

Fig. 2 Total densities of enchytraeids (on the left) and earthworms (on the right) per treatment. Treatments are: control (T), Cuprafor Micro ${ }^{\circledR}$ at $0.75 \mathrm{~kg} \mathrm{Cu}^{-h a^{-1}}$ (C1) and

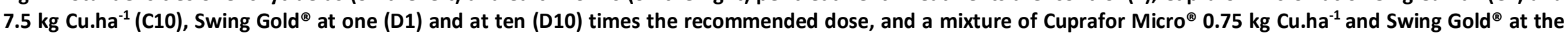
recommended dose $(\mathrm{M})$ 


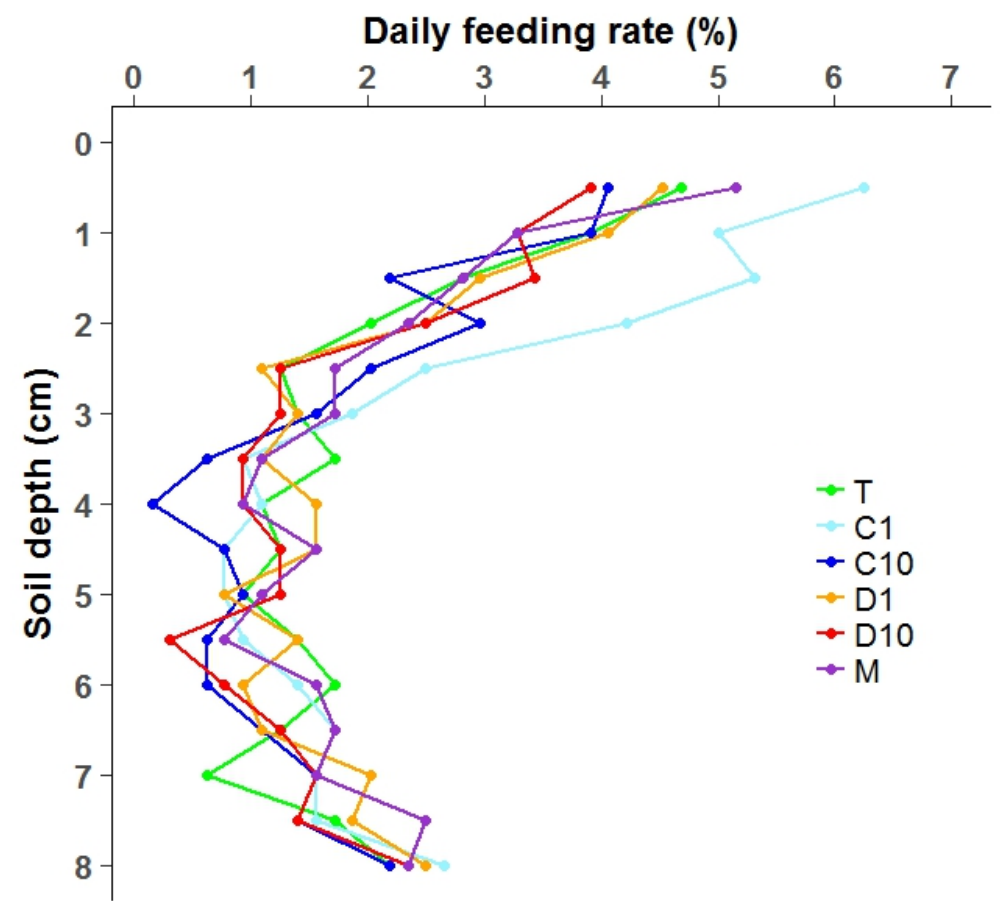

Fig. 3 Daily feeding activity (\%) with soil depth $(0.5$ to $8 \mathrm{~cm})$ from the four replicates of 16 sticks per

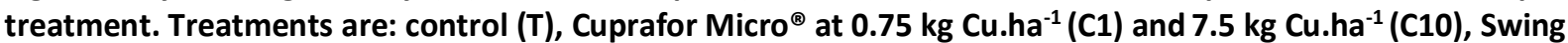
Gold $^{\circledR}$ at one (D1) and at ten (D10) times the recommended dose, and a mixture of Cuprafor Micro ${ }^{\circledR} 0.75 \mathrm{~kg}$ Cu.ha ${ }^{-1}$ and Swing Gold ${ }^{\circledR}$ at the recommended dose (M). 


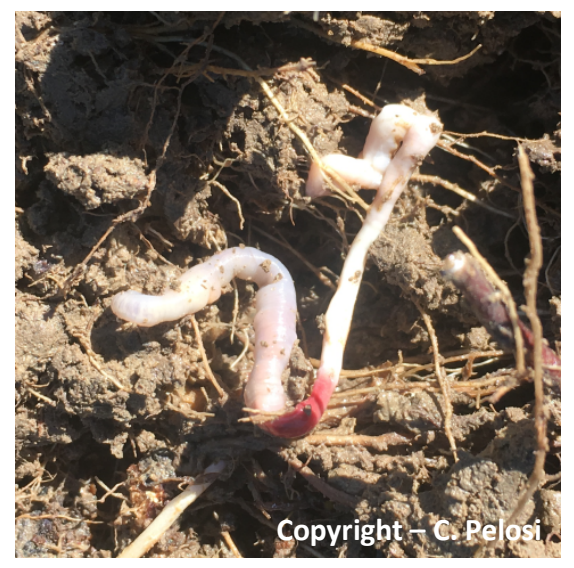

Fig. 4 Dead endogeic earthworm at the soil surface after the application of the Swing Gold ${ }^{\circledR}$ at ten times the recommended dose 
Table 1. Enchytraeid and earthworm densities, diversity metrics and community composition ( $n=4, \pm$ Standard Deviation) in the six treatments. For each row, asterisks indicate significant differences ('***’ $p<0.001$, ' $* * \prime p<0.01,{ }^{\prime * \prime} p<0.05$ ) between treatments with pesticides and the control. Treatments are: control (T), Cuprafor

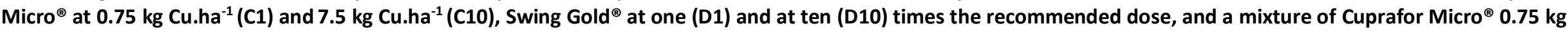
Cu.ha-1 and Swing Gold ${ }^{\circledR}$ at the recommended dose (M).

\begin{tabular}{|c|c|c|c|c|c|c|c|}
\hline $\begin{array}{l}\text { Soil faunal } \\
\text { group }\end{array}$ & Variable & $\mathbf{T}$ & C1 & C10 & D1 & D10 & M \\
\hline \multirow[t]{5}{*}{ Enchytraeids } & Density (ind. $\mathrm{m}^{-2}$ ) & $29667 \pm 11519$ & $27948 \pm 10458$ & $24574 \pm 5430$ & $29857 \pm 13684$ & $30653 \pm 8163$ & $36733 \pm 14726$ \\
\hline & Species richness & $9.8 \pm 1.0$ & $10 \pm 2.5$ & $9.8 \pm 1.7$ & $10.5 \pm 1$ & $9.8 \pm 1.5$ & $10.0 \pm 2.9$ \\
\hline & Shannon index & $6.61 \pm 0.75$ & $6.92 \pm 1.38$ & $6.32 \pm 1.07$ & $5.61 \pm 1.21$ & $6.06 \pm 1.26$ & $6.12 \pm 1.91$ \\
\hline & Evenness & $0.83 \pm 0.06$ & $0.84 \pm 0.03$ & $0.81 \pm 0.01$ & $0.73 \pm 0.07$ & $0.79 \pm 0.09$ & $0.61 \pm 0.11$ \\
\hline & $r$-strategists (\%) & $25.8 \pm 9.5$ & $26.1 \pm 5.3$ & $33.5 \pm 14.8$ & $33.7 \pm 22.1$ & $32.0 \pm 8.5$ & $33.7 \pm 20.1$ \\
\hline \multirow[t]{8}{*}{ Earthworms } & Density (ind. $\mathrm{m}^{-2}$ ) & $231 \pm 147$ & $211 \pm 84$ & $264 \pm 131$ & $214 \pm 109$ & $127 \pm 46$ & $231 \pm 126$ \\
\hline & Biomass (ind. m²) & $86.8 \pm 32.4$ & $79.5 \pm 28.4$ & $93.6 \pm 34.7$ & $78.9 \pm 27.1$ & $48.3 \pm 14.0$ & $83.1 \pm 33.9$ \\
\hline & Species richness & $7.0 \pm 1.4$ & $5.8 \pm 1.0$ & $6.3 \pm 1.7$ & $7.8 \pm 1.0$ & $2.8 \pm 0.5 * * *$ & $5.5 \pm 1.0$ \\
\hline & Shannon index & $3.07 \pm 0.74$ & $2.45 \pm 0.28$ & $2.48 \pm 0.51$ & $3.11 \pm 0.61$ & $1.17 \pm 0.08 * * *$ & $2.13 \pm 0.28 *$ \\
\hline & Evenness & $0.52 \pm 0.09$ & $0.51 \pm 0.14$ & $0.55 \pm 0.09$ & $0.57 \pm 0.09$ & $0.16 \pm 0.05 * * *$ & $0.44 \pm 0.04$ \\
\hline & Epigeic (ind. $m^{-2}$ ) & $12.9 \pm 13.0$ & $10.2 \pm 4.5$ & $7.4 \pm 3.9$ & $8.2 \pm 4.1$ & $0 \pm 0$ & $3.1 \pm 2.9$ \\
\hline & Endogeic (ind. $\mathrm{m}^{-2}$ ) & $184 \pm 124$ & $168 \pm 70$ & $211 \pm 121$ & $178 \pm 94$ & $124 \pm 45$ & $198 \pm 107$ \\
\hline & Anecic (ind. $m^{-2}$ ) & $34 \pm 13$ & $34 \pm 18$ & $47 \pm 18$ & $28 \pm 17$ & $3 \pm 1 * * *$ & $31 \pm 17$ \\
\hline
\end{tabular}


Table 2. Enchytraeid density (ind. $\left.\mathrm{m}^{-2}\right)$ per species $(n=4, \pm$ Standard Deviation) in the different treatments. Nomenclature follows Schmelz and Collado (2010). Categorization as $r$-strategists follows Graefe and Schmelz (1999). For each species, asterisks indicate significant differences $\left(^{\prime * * * \prime} p<0.001{ }^{\prime * * \prime} p<0.01,{ }^{\prime * \prime} p<0.05\right)$

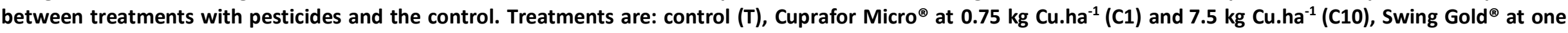
(D1) and at ten (D10) times the recommended dose, and a mixture of Cuprafor Micro ${ }^{\circledR} 0.75 \mathrm{~kg} \mathrm{Cu}$ ha $^{-1}$ and Swing Gold ${ }^{\boxplus}$ at the recommended dose (M).

\begin{tabular}{|c|c|c|c|c|c|c|c|c|c|c|}
\hline Genus & Species & Authority & $\mathbf{T}$ & C1 & C10 & D1 & D10 & $\mathbf{M}$ & $\begin{array}{l}\text { Mean } \\
\text { density }\end{array}$ & $\begin{array}{c}r- \\
\text { strategists }\end{array}$ \\
\hline Fridericia & galba & (Hoffmeister, 1843) & $6462 \pm 3233$ & $3979 \pm 2390$ & $3470 \pm 2033$ & $4138 \pm 2627$ & $3470 \pm 4398$ & $4361 \pm 3099$ & 4313 & \\
\hline Fridericia & ulrikae & Rota \& Healy, 1999 & $1592 \pm 2221$ & $0 \pm 0$ & $1528 \pm 3056$ & $446 \pm 891$ & $0 \pm 0$ & $1273 \pm 1928$ & 807 & \\
\hline Fridericia & christeri & Rota \& Healy, 1999 & $1496 \pm 1508$ & $1655 \pm 2166$ & $2578 \pm 2349$ & $2515 \pm 3248$ & $2737 \pm 3549$ & $2578 \pm 2358$ & 2260 & \\
\hline Fridericia & paroniana & Issel, 1904 & $1623 \pm 1881$ & $1878 \pm 2387$ & $446 \pm 555$ & $1560 \pm 1808$ & $1082 \pm 1254$ & $3565 \pm 5165$ & 1692 & \\
\hline Fridericia & isseli & Rota, 1994 & $4488 \pm 3971$ & $4838 \pm 3567$ & $4234 \pm 4918$ & $1942 \pm 1719$ & $3342 \pm 1214$ & $4870 \pm 3523$ & 3952 & \\
\hline Fridericia & nix & Rota, 1995 & $0 \pm 0$ & $191 \pm 127$ & $64 \pm 127$ & $127 \pm 147$ & $95 \pm 191$ & $64 \pm 74$ & 90 & \\
\hline Fridericia & maculata & Issel, 1905 & $0 \pm 0$ & $0 \pm 0$ & $223 \pm 446$ & $95 \pm 191$ & $0 \pm 0$ & $0 \pm 0$ & 53 & \\
\hline Fridericia & tuberosa & Rota, 1995 & $700 \pm 1088$ & $1783 \pm 2069$ & $1114 \pm 1262$ & $1432 \pm 1522$ & $3024 \pm 3912$ & $32 \pm 64$ & 1348 & \\
\hline Fridericia & viridula & Issel, 1904 & $127 \pm 255$ & $1846 \pm 3051$ & $0 \pm 0$ & $0 \pm 0$ & $0 \pm 0$ & $0 \pm 0$ & 329 & \\
\hline Enchytraeus & buchholzi & (Vejdovský, 1879) & $7417 \pm 5976$ & $6112 \pm 2735$ & $6303 \pm 1027$ & $4966 \pm 1422$ & $8149 \pm 4028$ & $9517 \pm 2307$ & 7056 & $x$ \\
\hline Enchytraeus & lacteus & $\begin{array}{l}\text { Nielsen \& } \\
\text { Christensen, } 1961\end{array}$ & $0 \pm 0$ & $0 \pm 0$ & $0 \pm 0$ & $0 \pm 0$ & $64 \pm 127$ & $0 \pm 0$ & 11 & $x$ \\
\hline Enchytraeus & bulbosus & $\begin{array}{l}\text { Nielsen \& } \\
\text { Christensen, } 1963\end{array}$ & $668 \pm 774$ & $382 \pm 764$ & $127 \pm 255$ & $159 \pm 191$ & $955 \pm 1178$ & $796 \pm 872$ & 515 & $x$ \\
\hline
\end{tabular}




\begin{tabular}{|c|c|c|c|c|c|c|c|c|c|c|}
\hline Enchytraeus & christenseni & Dózsa-Farkas, 1992 & $0 \pm 0$ & $0 \pm 0$ & $923 \pm 1846$ & $0 \pm 0$ & $95 \pm 191$ & $0 \pm 0$ & 170 & $x$ \\
\hline Buchholzia & fallax & Michaelsen, 1887 & $159 \pm 241$ & $382 \pm 329$ & $64 \pm 74$ & $64 \pm 74$ & $159 \pm 122$ & $32 \pm 64$ & 143 & \\
\hline Buchholzia & appendiculata & (Buchholz, 1962) & $127 \pm 147$ & $796 \pm 1592$ & $223 \pm 301$ & $6080 \pm 11906$ & $255 \pm 509$ & $95 \pm 122$ & 1263 & $x$ \\
\hline Enchytronia & parva & $\begin{array}{l}\text { Nielsen \& } \\
\text { Christensen, } 1959\end{array}$ & $2355 \pm 873$ & $1655 \pm 1003$ & $1337 \pm 767$ & $1082 \pm 535$ & $5029 \pm 3726$ & $2578 \pm 1464$ & 2339 & \\
\hline Marionina & Argentea & (Michaelsen, 1889) & $255 \pm 509$ & $191 \pm 382$ & $414 \pm 351$ & $3279 \pm 6473$ & $0 \pm 0$ & $3629 \pm 6677$ & 1295 & \\
\hline Marionina & communis & $\begin{array}{l}\text { Nielsen \& Christensen, } \\
1959\end{array}$ & $0 \pm 0$ & $0 \pm 0$ & $0 \pm 0$ & $0 \pm 0$ & $0 \pm 0$ & $95 \pm 191$ & 16 & \\
\hline Achaeta & unibulba & $\begin{array}{l}\text { Graefe, Dozsa-Farkas } \\
\text { \& Christensen, } 2005\end{array}$ & $191 \pm 382$ & $32 \pm 64$ & $0 \pm 0$ & $95 \pm 191$ & $0 \pm 0$ & $95 \pm 191$ & 69 & \\
\hline Achaeta & iberica & Graefe, 1989 & $1592 \pm 788$ & $1814 \pm 1227$ & $1114 \pm 1533$ & $1464 \pm 1896$ & $1369 \pm 1493$ & $2546 \pm 2473$ & 1650 & \\
\hline \multirow[t]{2}{*}{ Achaeta } & pannonica & Graefe, 1989 & $0 \pm 0$ & $0 \pm 0$ & $0 \pm 0$ & $0 \pm 0$ & $382 \pm 764$ & $0 \pm 0$ & 64 & \\
\hline & $\mathrm{NI}$ & & $411 \pm 282$ & $340 \pm 265$ & $414 \pm 217$ & $414 \pm 122$ & $446 \pm 221$ & $605 \pm 282$ & 438 & \\
\hline
\end{tabular}


Table 3. Earthworm density (ind. $\mathrm{m}^{-2}$ ) per species ( $\mathrm{n}=4, \pm$ Standard Deviation) in the different treatments. Nomenclature follows Bouché (1972) and Sims and Gerard (1999). Categorization with ecological categories follows Bouché (1977). For each species, asterisks indicate significant differences (‘*** $p<0.001, ‘ * * \prime p<0.01, ‘ * \prime p<$

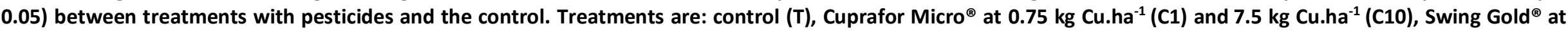
one (D1) and at ten (D10) times the recommended dose, and a mixture of Cuprafor Micro ${ }^{\circledR} 0.75 \mathrm{~kg}^{\mathrm{Cu}} \mathrm{ha}^{-1}$ and Swing Gold ${ }^{\circledR}$ at the recommended dose (M).

\begin{tabular}{|c|c|c|c|c|c|c|c|c|c|c|}
\hline Genus & Species & Authority & $\mathbf{T}$ & C1 & C10 & D1 & D10 & M & Mean density & Ecological category \\
\hline Lumbricus & castaneus & Savigny, 1826 & $11.7 \pm 10.9$ & $10.2 \pm 4.5$ & $7.4 \pm 3.9$ & $7.0 \pm 4.7$ & $0.0 \pm 0.0$ & $1.6 \pm 2.2$ & 6.3 & epigeic \\
\hline Lumbricus & rubellus & Hoffmeister, 1843 & $0.0 \pm 0.0$ & $0.0 \pm 0.0$ & $0.0 \pm 0.0$ & $0.4 \pm 0.8$ & $0.0 \pm 0.0$ & $0.0 \pm 0.0$ & 0.1 & epigeic \\
\hline Dendrobaena & mammalis & Savigny, 1826 & $1.2 \pm 2.3$ & $0.0 \pm 0.0$ & $0.0 \pm 0.0$ & $0.8 \pm 0.9$ & $0.0 \pm 0.0$ & $1.3 \pm 3.1$ & 0.6 & endogeic \\
\hline Allolobophora & chlorotica & Savigny, 1826 & $4.7 \pm 4.0$ & $1.6 \pm 2.0$ & $3.9 \pm 4.7$ & $5.5 \pm 5.3$ & $0.4 \pm 0.8$ & $5.5 \pm 7.0$ & 3.6 & endogeic \\
\hline Allolobophora & icterica & Savigny, 1826 & $158.6 \pm 111.1$ & $157.8 \pm 59.7$ & $202.0 \pm 121.7$ & $141.8 \pm 63.0$ & $123.4 \pm 45.6$ & $183.6 \pm 96.8$ & 161.2 & endogeic \\
\hline Allolobophora & muldali & Omodeo 1956 & $7.8 \pm 15.6$ & $0.0 \pm 0.0$ & $1.2 \pm 2.3$ & $4.7 \pm 9.4$ & $0.0 \pm 0.0$ & $0.0 \pm 0.0$ & 2.3 & endogeic \\
\hline Octolasion & cyaneum & Savigny, 1826 & $0.0 \pm 0.0$ & $0.0 \pm 0.0$ & $0.4 \pm 0.8$ & $0.0 \pm 0.0$ & $0.0 \pm 0.0$ & $0.0 \pm 0.0$ & 0.1 & endogeic \\
\hline Aporrectodea & caliginosa & Savigny, 1826 & $12.5 \pm 15.0$ & $8.2 \pm 9.5$ & $2.3 \pm 2.0$ & $25.4 \pm 25.9$ & $0.0 \pm 0.0$ & $8.6 \pm 5.8$ & 9.5 & endogeic \\
\hline Aporrectodea & rosea & Savigny, 1826 & $0.4 \pm 0.8$ & $0.0 \pm 0.0$ & $0.8 \pm 1.6$ & $0.8 \pm 1.6$ & $0.0 \pm 0.0$ & $0.0 \pm 0.0$ & 0.3 & endogeic \\
\hline Arporrectodea & longa & Ude, 1885 & $8.2 \pm 5.9$ & $9.0 \pm 6.3$ & $10.9 \pm 6.4$ & $4.3 \pm 3.2$ & $0.8 \pm 0.9$ & $1.6 \pm 3.1$ & 5.8 & anecic \\
\hline Aporrectodea & giardi & Ribaucourt, 1901 & $3.5 \pm 2.7$ & $1.2 \pm 1.5$ & $0.8 \pm 1.6$ & $7.0 \pm 5.3$ & $0.8 \pm 1.6$ & $5.9 \pm 5.6$ & 3.2 & anecic \\
\hline Lumbricus & terrestris & Linnaeus, 1758 & $22.3 \pm 13.2$ & $23.4 \pm 13.8$ & $34.8 \pm 13.8$ & $16.8 \pm 12.7$ & $1.2 \pm 0.8 * * *$ & $23.0 \pm 14.7$ & 20.2 & anecic \\
\hline
\end{tabular}


Table 4. Percentage of minimum detectable difference (\% MDD) relative to the control for key earthworm variables. Treatments with pesticides are: Cuprafor Micro ${ }^{\circledR}$ at

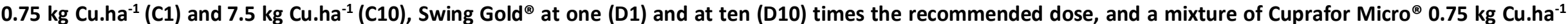
and Swing Gold ${ }^{\circledR}$ at the recommended dose (M).

\begin{tabular}{|c|c|c|c|c|c|}
\hline \multirow[b]{2}{*}{ Variable } & \multicolumn{5}{|c|}{ \% MDD } \\
\hline & C1 & $\mathrm{C} 10$ & D1 & D10 & M \\
\hline Epigeic density (ind. $\mathrm{m}^{-2}$ ) & -33.4 & -65.9 & -56.7 & -148.7 & -115.3 \\
\hline L. castaneus density (ind. m $^{-2}$ ) & -20.2 & -54.6 & -61.0 & -140.1 & -123.9 \\
\hline Endogeic density (ind. $\mathrm{m}^{-2}$ ) & -9.2 & +18.1 & -3.6 & -31.3 & +8.8 \\
\hline A. caliginosa density (ind. $\mathrm{m}^{-2}$ ) & -33.1 & -66.8 & +167.1 & -81.4 & -27.3 \\
\hline Anecic density (ind. $\mathrm{m}^{-2}$ ) & -1.2 & +37.5 & -16.9 & -55.1 & -10.3 \\
\hline A. longa density (ind. m $^{-2}$ ) & +12.2 & +43.0 & -47.5 & -80.1 & -80.2 \\
\hline L. terrestris density (ind. $\mathrm{m}^{-2}$ ) & +5.7 & +60.9 & -25.5 & -71.1 & +3.9 \\
\hline
\end{tabular}

